(c) American Dairy Science Association, 2004.

\title{
Partial Characterization of Dextran-Degrading Enzyme Obtained from Blue Cheese
}

\author{
Y. Wang, A. Suzuki, T. Tanaka, H. Kumura, and K. Shimazaki \\ Dairy Science Laboratory, Graduate School of Agriculture, \\ Hokkaido University, Sapporo 060-8589, Japan
}

\begin{abstract}
Degradation of dextran beads was observed when the water-soluble fraction of a blue cheese extract was applied to the top of a Sephadex G-150 or G-200 column. This phenomenon suggests the presence of a specific enzyme that can hydrolyze dextran. After removal of casein components from the blue cheese fraction, ammonium sulfate treatment and gel filtration chromatography were performed to isolate the enzyme fraction. The enzymatic products were analyzed by thin-layer chromatography and gel filtration chromatography and identified as isomaltooligosaccharides. The isoelectric point of this enzyme fraction was approximately 4.9, as determined by isoelectric focusing using Rotofor, and the molecular weight of the fraction was $65 \mathrm{kDa}$, as estimated by sodium dodecyl sulfate (SDS)-PAGE. Optimum $\mathrm{pH}$ for enzymatic activity was 5.0 to 5.3. A partial $\mathrm{N}$-terminal amino acid sequence of 20 residues was determined to be ATPDEWRSRSIYFMLTDRGA from an enzyme fraction further purified by ion-exchange chromatography and native PAGE. This sequence showed a maximum homology of $80 \%$ with $\alpha$-amylase or Taka amylase that originated from various microorganisms.
\end{abstract}

(Key words: blue cheese, dextran, enzyme, Penicillium roquefort)

Abbreviation key: TLC = thin-layer chromatography.

\section{INTRODUCTION}

In an attempt to fractionate the water-soluble fraction of a blue cheese extract into separate protein components using a Sephadex column, we observed degradation of the Sephadex G-150 or G-200 gel and were unsuccessful in performing chromatographic separation. This indicates the presence of an active compound

Received October 20, 2003

Accepted December 14, 2003.

Corresponding author: Kei-ichi Shimazaki; e-mail: simazaki@ anim.agr.hokudai.ac.jp. in the blue cheese extract that can break down the Sephadex gel, which is a polymer consisting of dextran cross-linked with epichlorohydrin. Blue cheese is fermented using strains of lactic acid bacteria and the mold Penicillium roquefort, which produce enzymes. Such enzymatic function contributes to the flavor of the cheese during the ripening process. The presence of alkaline phosphatase activity (Rosenthal et al., 1996), transfructosylating enzyme (Jang and Hang, 1996), acid aspartyl proteinase (Bracq et al., 1997), and protease (Larsen et al., 1998) has been reported in blue cheese. However, dextran-degrading activity had not been reported before we found such activity in watersoluble fractions from blue cheese (Shimazaki et al., 2003). These enzyme fractions did not degrade Sephadex G-10, G-25, or G-100, Sepharose CL-2B or CL-4B, Sephacryl S-300 or S-400, agar, agarose, or Toyopearl gel. For this study, we conducted further purification of this enzyme fraction from blue cheese, separation of the products from soluble dextran by the enzyme reaction, and determination of the partial $\mathrm{N}$-terminal amino acid sequence.

\section{MATERIALS AND METHODS}

\section{Materials}

The blue cheese used was Bleu des Causses (Beulet, France), which was processed from raw milk. Dextran (MW 100,000 to 200,000) was purchased from Kishida Chemicals Co., Ltd (Osaka). Nelson reagent was obtained from Katayama Kagaku (Tokyo). Sephadex gel was a product of Amersham Biosciences (Uppsala). Toyopearl HW55, DEAE-Toyopearl 650S, and TSK-GEL G3000SW were obtained from Tosoh Co. (Tokyo). Silver Stain "Daiichi" was a product of Daiichi Pure Chemicals Co., Ltd (Tokyo).

\section{Enzyme Preparation}

Blue cheese was mixed with the same weight of PBS, $\mathrm{pH}$ 7.5, in a Stomacher 80 blender (Lab Blender, Organo, Tokyo). The water-soluble fraction was separated from the paste-like mixture by centrifugation at 3000 $\times g$ for $15 \mathrm{~min}$ at $15^{\circ} \mathrm{C}$. To remove casein components, 
the $\mathrm{pH}$ of the water-soluble fraction was adjusted to 4.5 to 4.6 with $\mathrm{HCl}$ solution, followed by centrifugation at $10,000 \times g$ for $30 \mathrm{~min}$ at $15^{\circ} \mathrm{C}$. The $\mathrm{pH}$ of the supernatant was adjusted to 6.8 with $\mathrm{NaOH}$ solution, and the precipitate was removed by centrifugation. Then, ammonium sulfate was added to the supernatant to $80 \%$ saturation. After standing overnight at $4^{\circ} \mathrm{C}$, the precipitate formed was collected by centrifugation at 10,000 $\times g$ for 30 min at $4^{\circ} \mathrm{C}$. The precipitate was dissolved in a small amount of water and dialyzed against $25 \mathrm{mM}$ Tris-HCl buffer, $\mathrm{pH} 7.5$, for $2 \mathrm{~d}$ in the cold room to remove ammonium sulfate. The dialyzed sample solution was filtered with a membrane filter (cellulose acetate, pore size $0.45 \mu \mathrm{m}$; Advantec Toyo Roshi Kaisha, Ltd., Tokyo) to remove small particles. Then, gel filtration chromatography was performed using a Toyopearl HW55 column $(25 \mathrm{~mm}$ i.d. $\times 495 \mathrm{~mm}$, separation range for globular proteins of 1000 to 700,000) and an eluent of $25 \mathrm{mM}$ Tris- $\mathrm{HCl}$ buffer, $\mathrm{pH} 7.5$, containing $0.3 \mathrm{M}$ $\mathrm{NaCl}$. The dextran-degradation activity of each fraction was measured by the methods described below. The active fraction was purified further by anion-exchange chromatography using DEAE-Toyopearl $650 \mathrm{~S}$ (10 mm i.d. $\times 95 \mathrm{~mm}$ ) and an eluent of $25 \mathrm{mM}$ Tris-HCl buffer at $\mathrm{pH} 7.3$ with a gradient elution of 0 to $1 \mathrm{M} \mathrm{NaCl}$ concentration. The eluent volume for chromatography was $30 \mathrm{~mL}$. The eluate was monitored by the absorbance at $280 \mathrm{~nm}$ during gel filtration chromatography and ion-exchange chromatography.

\section{Enzyme Activity Measurements}

Two methods for enzyme activity measurements were used. For the Sephadex-test tube method, a small amount of sample solution was mixed with 2 to $3 \mathrm{~mL}$ of a slurry of Sephadex G-150 or G-200 in a small glass tube $(0.8 \times 10 \mathrm{~cm})$ and kept at room temperature for 24 to $48 \mathrm{~h}$. For samples that possessed enzyme activity, the Sephadex gel dissolved, and its residual volume decreased as mentioned in our previous report (Shimazaki et al., 2003). Eventually the gel disappeared, leaving a small amount of white residue at the bottom of the test tube. This method was useful even for enzyme extracts that were very turbid. For quantitative measurement, the height of the remaining gel volume was measured. The second method involves measuring the amount of reducing sugar liberated from dextran using colorimetry. One milliliter of $2 \%$ (wt/vol) dextran solution in $50 \mathrm{~m} M$ sodium citrate buffer at $\mathrm{pH} 5.2$ was mixed with $0.5 \mathrm{~mL}$ of sample solution. After incubation at $40^{\circ} \mathrm{C}$ for $1 \mathrm{~h}$, the reducing sugar liberated was assayed using a colorimetric method modified from Nelson (1944) and Somogyi (1952). Briefly, $0.2 \mathrm{~mL}$ of reaction mixture was mixed with $0.2 \mathrm{~mL}$ of copper reagent and kept in boiling water for $10 \mathrm{~min}$. After cooling, 0.2 $\mathrm{mL}$ of Nelson reagent was added. Then, the volume was adjusted up to $5 \mathrm{~mL}$ and cooled for $15 \mathrm{~min}$. Absorbance of the dark blue solution was measured at 500 or 660 $\mathrm{nm}$. The copper reagent was a mixture of one volume of solution A (15\% copper sulfate solution) and 25 volumes of solution B ( $1 \mathrm{~L}$ of solution B contained $25 \mathrm{~g}$ of anhydrous sodium carbonate, $25 \mathrm{~g}$ of potassium sodium tartarate, $20 \mathrm{~g}$ of sodium hydrogencarbonate, and 200 $\mathrm{g}$ of anhydrous sodium sulfate).

\section{Thin-Layer Chromatography Analysis of Sugars}

Hydrolytic products from dextran were analyzed by TLC using aluminum-backed silica-gel-60 sheets (Merck KdaA, Darmstadt, Germany). Enzyme-dextran mixtures at each reaction time were boiled for $3 \mathrm{~min}$ to stop the reaction, and the remaining dextran was removed by the addition of 2 volumes of ethanol followed by centrifugation. Chromatographic development was carried out with a solvent system of nitromethane:1-propanol:water (2:5:1.5). Sugars were detected by spraying with $\alpha$-naphthol solution (300 mg/ L) containing $\mathrm{H}_{2} \mathrm{SO}_{4}(5 \%)$ and methanol (45\%) and by heating at $120^{\circ} \mathrm{C}$ for $5 \mathrm{~min}$.

\section{Gel Filtration Chromatography of Sugars}

Molecular size distribution of dextran hydrolysates was studied by gel filtration chromatography using a TSK-GEL G3000SW column $(7.5 \mathrm{~mm}$ i.d. $\times 60 \mathrm{~cm})$. The separation range of this column is 2000 to 70,000 , according to the manufacturer's manual. The eluate was pure water, and the flow rate was $1.0 \mathrm{~mL} / \mathrm{min}$. The eluent was monitored using a Refractomonitor RI8000 (Tosoh).

\section{Electrophoretic Separation}

The SDS-PAGE with Tris-glycine buffer system (Laemmli, 1970) was performed to determine purity and to estimate molecular weight of the enzyme obtained by chromatographic methods. To see protein bands, a silver-staining method or a dye-staining method with Coomassie brilliant blue R-250 dissolved in methanol/acetic acid/water (3:1:6) was used. Native PAGE with Tris-glycine buffer system (pH 8.3) (Davis, 1964) was carried out to isolate the enzyme. The size of the slab gel was $84 \mathrm{~mm}$ wide $\times 50 \mathrm{~mm}$ high $\times$ and 2 $\mathrm{mm}$ thick. Acrylamide concentration for native PAGE and SDS-PAGE was $12.5 \%$ (wt/vol). To assay the enzyme activity of segments from native PAGE, duplicate electrophoretic separations were conducted simultaneously. One slab gel was carved into 1-mm strips along 
the lane containing protein bands after electrophoresis. Each segment separated was broken down to extract protein from the gel matrix, and the supernatant was assayed with its enzyme activity by the Sephadex-test tube method and colorimetric method. Another gel was stained by silver-stain to visualize the protein bands.

\section{Preparative Electrophoresis by Rotofor}

Preparative isoelectric focusing was performed using a Rotofor system (Bio-Rad, Richmond, CA). The crude enzyme preparation after gel filtration chromatographic operation was dialyzed against water for desalting. Then, $1.5 \mathrm{~mL}$ of the sample solution was mixed with $2.5 \mathrm{~mL}$ of premixed Ampholine $(\mathrm{pH}$ range of 3.5 to 9.5; Amersham Biosciences) and $46 \mathrm{~mL}$ of pure water. The run was operated at $15 \mathrm{~W}$ constant power, with the standard Rotofor cell at $4^{\circ} \mathrm{C}$, and was completed in $5 \mathrm{~h}$. Then, $\mathrm{pH}$ values and the dextran-degradation activity were measured for each fraction. Protein content of each fraction was determined by absorbance at $280 \mathrm{~nm}$.

\section{pH-Dependence of Activity}

The $\mathrm{pH}$-dependence of the enzymatic activity of the water-soluble fraction from blue cheese was determined between $\mathrm{pH} 3$ and 7 using McIlvaine buffer (sodium citrate-phosphate buffer). Release of reducing sugars was assayed colorimetrically, as described above.

\section{Protein Concentration Measurement}

Protein content of blue cheese and water-soluble fractions were determined by Kjeldahl using a protein factor of 6.38. Protein concentrations of other fractions were determined spectrophtometrically assuming an $\mathrm{E}^{1 \%}{ }_{1 \mathrm{~cm}}$ value of 10 at $280 \mathrm{~nm}$.

\section{N-Terminal Amino Acid Sequence Determination}

$\mathrm{N}$-Terminal amino acid sequence was determined by automated Edman degradation with a Procise49X cLC protein sequencer (Applied Biosystems Japan Ltd., Tokyo). For this analysis, proteins extracted from polyacrylamide gel were blotted on a PVDF membrane using ProSorb (Applied Biosystems).

\section{RESULTS}

\section{Products from Dextran by Blue Cheese Enzyme}

To separate the Sephadex-degrading portion of the water-soluble fractions that showed Sephadex-degrading activity, gel chromatography was conducted (Figure

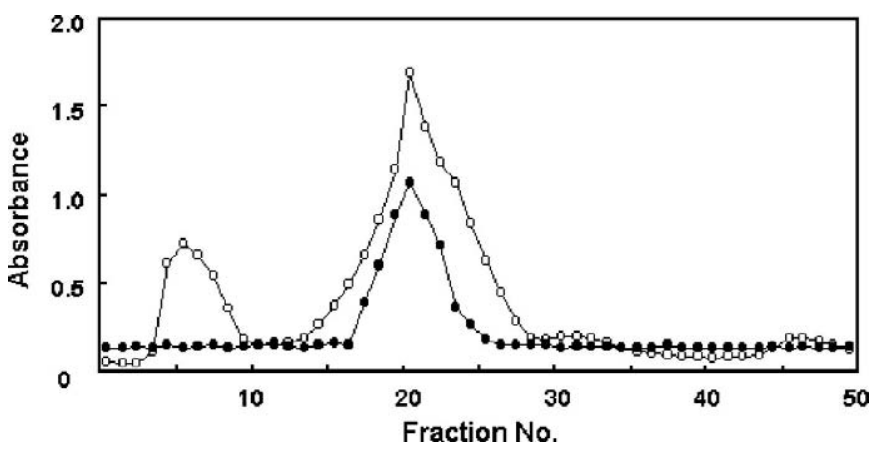

Figure 1. Gel filtration chromatographic pattern of water-soluble fractions from blue cheese. Separation was performed using Toyopearl HW55 $(25 \mathrm{~mm}$ ID $\times 495 \mathrm{~mm})$ with a solution of $25 \mathrm{mM}$ Tris$\mathrm{HCl}$ buffer, $\mathrm{pH} 7.5$, containing $0.3 \mathrm{M} \mathrm{NaCl}$. Flow rate was $1.0 \mathrm{~mL} /$ min and 3.5-mL fractions were collected. Absorbance at $280 \mathrm{~nm}$ was measured for each fraction to quantify protein (- $\left.{ }_{-}\right)$and enzyme activity was assayed by the Somogyi-Nelson method (Absorbance at $500 \mathrm{~nm},-\mathbf{-}$-). Sample applied on the column was $0.1 \mathrm{~g} / 5 \mathrm{~mL}$.

1), and enzyme activity was measured by the Sephadextest tube method. Sephadex gel is a polymer consisting of dextran cross-linked with epichlorohydrin. Dextran is a polymer of D-glucose units linked predominantly with $\alpha-\mathrm{D}(1->6)$ bonds, and often includes $\alpha-\mathrm{D}(1->3)$ or $\alpha-\mathrm{D}(1->2)$ branches. Therefore, soluble dextran also was used for the measurement of the enzyme activity. Dextran-degrading activity was observed in fraction no. 21 by both the Sephadex-test tube method and the colorimetric assay. Contaminants in this crude enzyme fraction were not likely to disturb the dextran-degrading reaction and identification of the reaction products. Therefore, a dextran solution mixed with crude enzyme fraction was analyzed by gel filtration chromatography and thin-layer chromatography (TLC) in order to identify the reaction products.

In Figure 2, gel chromatographic patterns of dextran degraded by the enzyme fraction are shown. Dextran gel used for this experiment showed a broad peak after the void volume $\left(\mathrm{V}_{0}\right)$ of the column. The peak at $\mathrm{V}_{0}$ disappeared, and the peak of molecular size distribution shifted to smaller sizes with increasing reaction time, indicating degradation of dextran by the crude enzyme fractions of blue cheese. The products from reaction of dextran with the crude enzyme fractions were analyzed by TLC as shown in Figure 3. At 12 h, several spots were clearly visible and coincided with those of glucose and isomaltooligosaccharides, but not with maltooligosaccharides. After $12 \mathrm{~h}$ of reaction, spots of glucose (G), isomaltose (IG2), isomaltotriose (IG3), and isomaltotetraose (IG4) were observed.

\section{Purification of the Enzyme}

An enzymatic fraction obtained by gel chromatography (Figure 1, fraction no. 21) was further purified by 


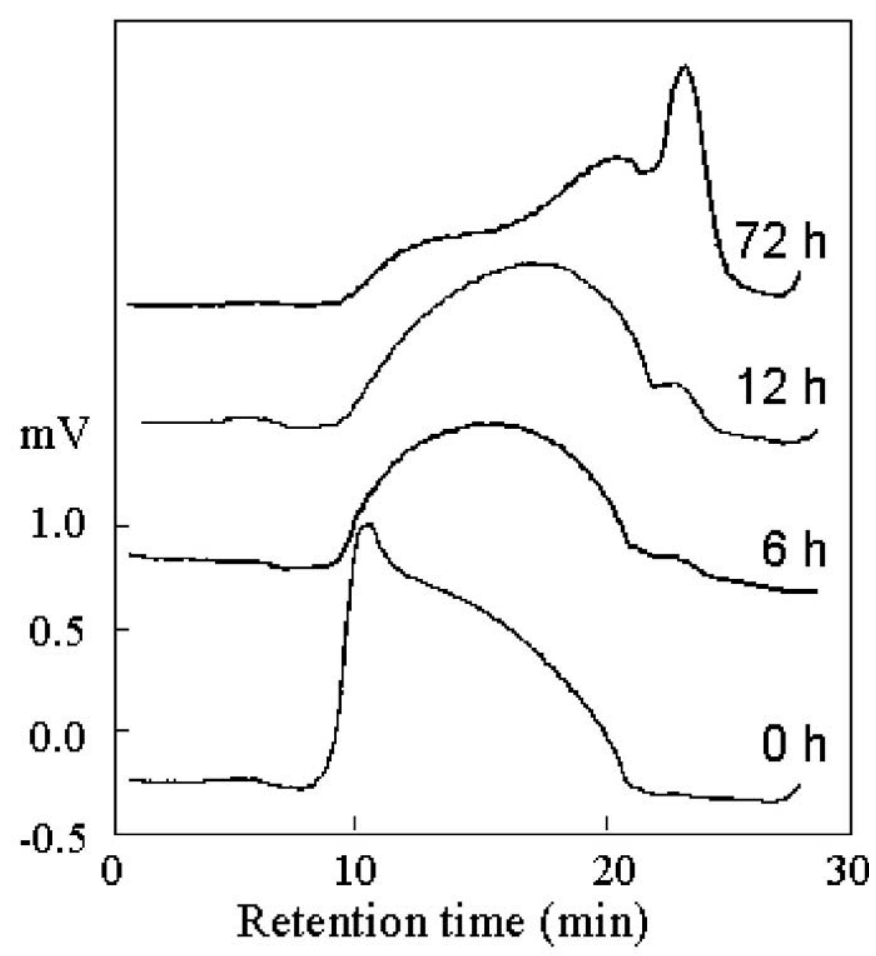

Figure 2. Gel chromatographic profiles of dextran degraded with crude blue cheese enzyme fractions over different reaction times. Column was TSKgel G3000-SW (7.5 mm I.D. $\times 60 \mathrm{~cm}$ ) and the eluent was pure water. Sample volume applied was $100 \mu \mathrm{L}$ and the eluate was monitored by refractive index. Flow rate was $1.0 \mathrm{~mL} / \mathrm{min}$.

ion-exchange chromatography with a DEAE-Toyopearl column as shown in Figure 4. Enzyme activity appeared at $0.75 \mathrm{M} \mathrm{NaCl}$ concentrations (fraction no. 12). This fraction showed several protein bands by SDS-PAGE (Figure 4B), therefore chromatography was repeated. However, some enzymatic activity was lost upon repeat chromatography. Therefore, separation by isoelectric focusing using Rotofor was attempted with gel chromatographic fraction no. 21. Each fraction separated by Rotofor contained carrier ampholite, and this reagent disturbed the colorimetric assay of the reduced sugars. Therefore, the Sephadex-test tube method was used to identify those fractions that contained enzyme activity. By this method, fraction no. 3 (marked by arrow in Figure 5A) was found to possess activity. The SDSPAGE pattern of this fraction is shown in Figure 5B. The distribution of protein bands was almost the same as that for the fraction obtained by ion-exchange chromatography. Using the Rotofor system, the isoelectric point of this enzyme was estimated to be 4.9.

The optimum $\mathrm{pH}$ for activity of the enzyme fraction purified by gel filtration chromatography was estimated to be 5.0 to 5.3. The amount of enzyme contained in blue cheese and its yield from $50 \mathrm{~g}$ of cheese are shown

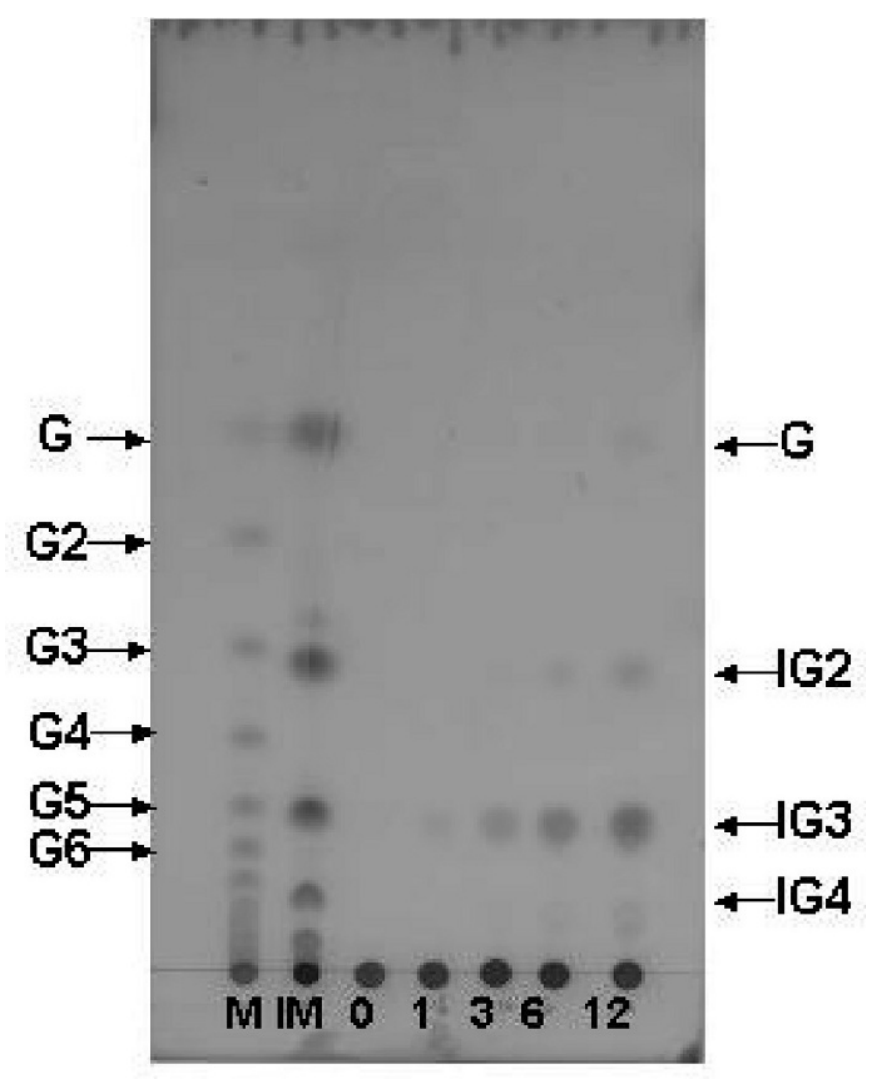

Figure 3. Thin-layer chromatographic patterns of products from reaction between dextran and crude enzyme extracts of blue cheese. The reaction mixture aliquots were boiled at the indicated times and spotted on TLC plates. M, maltooligosaccharides; IM, isomaltooligosaccharides; G, glucose; G2, maltose; G3, maltotriose; G4, maltotetraose; G5, maltopentaose; G6, maltohexaose; IG2, isomaltose; IG3, isomaltotriose; IG4, isomaltotetraose.

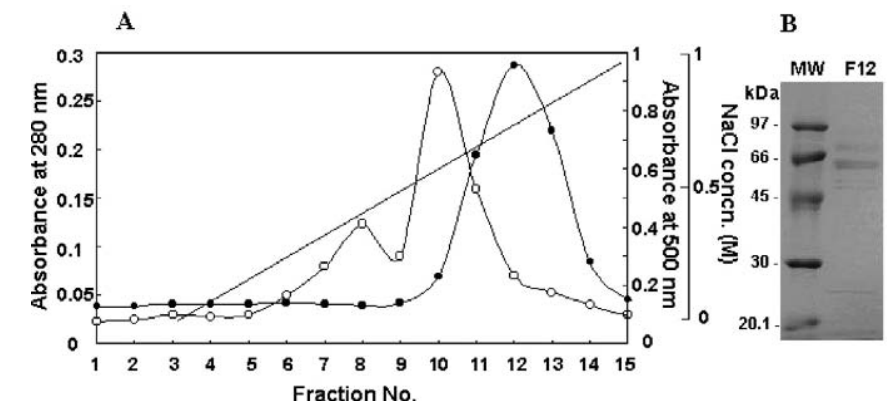

Figure 4. Ion-exchange chromatography profile (A) of active fractions obtained from gel filtration chromatography as shown in Figure 1. The DEAE-Toyopearl $650 \mathrm{~S}(10 \mathrm{~mm}$ ID $\times 95 \mathrm{~mm})$ was used for separation. Eluent was $25 \mathrm{~m} M$ Tris-HCl buffer at $\mathrm{pH} 7.3$, with a 0 to $1 M \mathrm{NaCl}$ concentration gradient (shown as a linear curve). Twomilliliter fractions were collected. The amount of protein was measured at an absorbance of $280 \mathrm{~nm}$, (-O-) and enzyme activity was measured at an absorbance of $500 \mathrm{~nm}$ (-)- In B, SDS-PAGE pattern of fraction 12 (F12) detected by silver-staining is shown. MW indicates molecular weight standard proteins. 


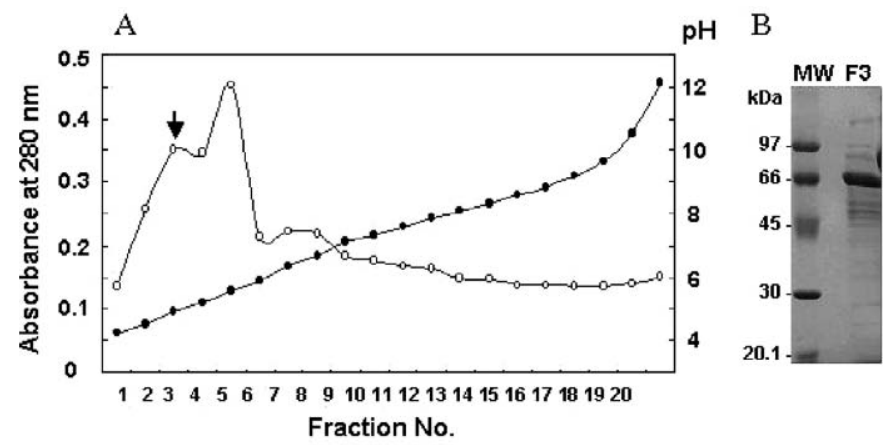

Figure 5. Separation profile of crude enzyme fractions by Rotofor (A) and SDS-PAGE pattern of the fraction stained by Coomassie brilliant blue R-250 (B). By Rotofor, 2.5-mL fractions were collected and were measured for protein content at an absorbance of $280 \mathrm{~nm}$ (-O-) and for $\mathrm{pH}$ (-0-). Fraction no. 3 (F3, arrow mark) showed enzyme activity as measured by the Sephadex-test tube method and analyzed with SDS-PAGE. MW indicates molecular weight standard proteins.

in Table 1. By ion-exchange chromatography, the enzyme was purified 149-fold. Activity measurement of water-soluble fractions was carried out by the Sephadex-test tube method, and the activity measurements for chromatographic fractions were performed by both the Sephadex-test tube method and colorimetric method. Therefore, the activity value for the watersoluble fractions was calibrated with the value of gel filtration chromatography fractions measured by the same method.

\section{Partial N-Terminal Sequence of the Enzyme}

To determine the amino acid sequence of the dextrandegrading enzyme extracted from blue cheese, further purification of the enzyme fraction was necessary. The results of ion-exchange chromatography and Rotofor separation showed that separation based on charge difference was effective. Therefore, native PAGE separa-
A
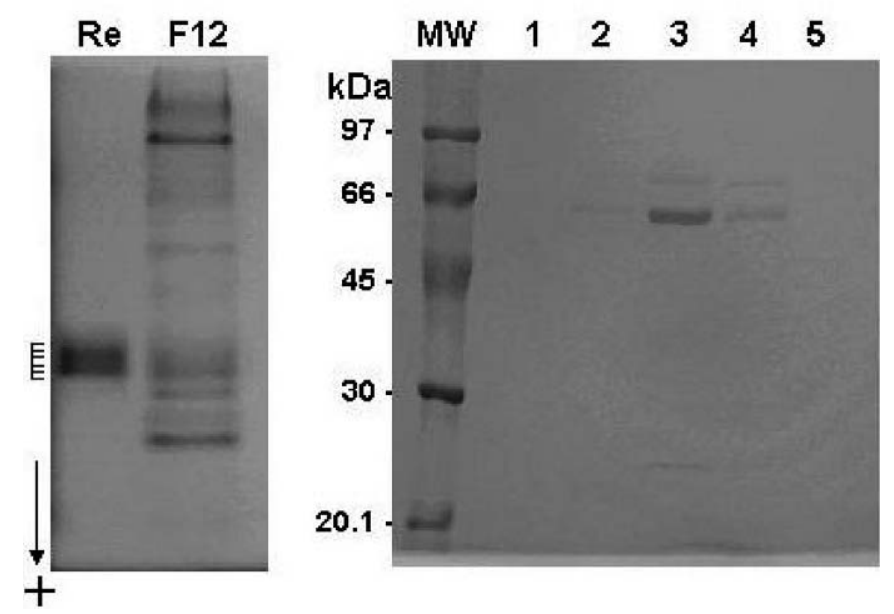

Figure 6. Electrophoretic profiles of enzyme fractions. Pattern (A) shows native PAGE patterns of enzyme fractions (F12) shown in Figure 4; Re indicates re-electrophoretic analysis and this lane was cut into $1 \mathrm{~mm}$ strips shown as comb. Pattern B is obtained by SDSPAGE and the fractions 1 to 5 are representing comb (extracted from lane Re of pattern A) top to bottom, respectively. Protein bands were detected by silver-staining. MW indicates molecular weight standard proteins.

tion was performed on the fraction obtained by ionexchange chromatography. Lane F12 in Figure 6A contains fraction no. 12 obtained from ion-exchange chromatography (Figure 4); this lane of the unstained gel was cut into 20 segments. The segments showing enzyme activity were separated under the same electrophoretic conditions and the protein band having enzymatic activity appeared in the broad range as shown in lane Re (Figure 6A). This broad protein band was cut into 5 pieces from which proteins were extracted. Then, each extract containing a protein component was assayed for enzyme activity. Three samples (strips no. 2 to 4 from top to bottom in Figure 6A comb) showed

Table 1. Purification of dextran-degrading enzyme from blue cheese.

\begin{tabular}{|c|c|c|c|c|c|c|c|c|}
\hline Step & $\begin{array}{l}\text { Volume } \\
(\mathrm{mL})\end{array}$ & \multicolumn{3}{|c|}{ Activity $^{1}$} & \multicolumn{2}{|c|}{ Protein $^{2}$} & \multicolumn{2}{|c|}{ Purification } \\
\hline Chromatography fraction & 3.5 & 64 & 244 & 5 & 1.68 & 5.88 & 41.4 & 6 \\
\hline $\begin{array}{l}\text { Ion exchange } \\
\text { chromatography fraction }\end{array}$ & 2 & 57 & 114 & 2 & 0.07 & 0.14 & 1028.6 & 149 \\
\hline
\end{tabular}

${ }^{1}$ One unit of enzyme activity was defined as that required to produce an increase in absorbance at $550 \mathrm{~nm}$ of $0.01 / \mathrm{h}$ with a final concentration of $2 \%(\mathrm{wt} / \mathrm{vol})$ dextran as the substrate at $\mathrm{pH} 5.2$.

${ }^{2}$ Protein concentration of cheese, water-soluble fraction, and ammonium sulfate fraction were determined by Kjeldahl. Protein concentrations of solutions from gel filtration and ion-exchange chromatography were determined by UV absorption at $280 \mathrm{~nm}$.

${ }^{3}$ Enzyme activity was measured by the Sephadex-test tube method and calibrated using gel filtration chromatographic fractions. 
Table 2. N-terminal amino acid sequence of the dextran-degrading enzyme and other enzymes having homologous sequences. Enzymes having homologous sequences included $\alpha$-amylases or Taka amylases from various microorganisms. The enclosed letters indicate the amino acid residues that differ from the sequence of the enzyme from blue cheese.

\begin{tabular}{|c|c|c|}
\hline Origin & Sequences & Identities \\
\hline Blue cheese enzyme & ATPDEWRSRSIYFMLTDRGA (1-20) & \\
\hline Thermomyces lanuginosus ${ }^{1}$ & ATPDEWKAQSIYFMLTDRFA (19-38) & $80 \%$ \\
\hline Emericella nidulans ${ }^{2}$ & ATPAEWRSQSIYFLLTDRFA (16-35) & $80 \%$ \\
\hline Aspergillus niger ${ }^{3}$ & ATPAEWRSQSIYFLLTDRFA (17-36) & $80 \%$ \\
\hline Aspergillus oryzae 4 & ATPADWRSQSIYFLLTDRFA $(22-41)$ & $75 \%$ \\
\hline Aspergillus shirousami ${ }^{5}$ & ATPADWRSQSIYFLLTDRFA $(22-41)$ & $75 \%$ \\
\hline Aspergillus flavus ${ }^{6}$ & ATPADWRSQSIYFLLTDRFA $(22-41)$ & $75 \%$ \\
\hline Aspergillus awamor ${ }^{7}$ & ATPADWRSQSIYFLLTDRFA (22-41) & $75 \%$ \\
\hline \multicolumn{3}{|l|}{${ }^{1} \mathrm{~A} 48521-1$ (DAD). } \\
\hline \multicolumn{3}{|l|}{${ }^{2} \mathrm{AF} 208225-1$ (DAD). } \\
\hline \multicolumn{3}{|l|}{${ }^{3} \mathrm{X} 52756$ (DAD) } \\
\hline \multicolumn{3}{|l|}{${ }^{4} \mathrm{D} 00434(\mathrm{DAD})}$. \\
\hline \multicolumn{3}{|l|}{${ }^{5} \mathrm{D} 10461$ (DAD). } \\
\hline \multicolumn{3}{|l|}{${ }^{6} \mathrm{~F} 139925$ (DAD). } \\
\hline${ }^{7} \mathrm{~B} 48305$ (PIR). & & \\
\hline
\end{tabular}

dextran-degrading activity by the Sephadex-test tube method and colorimetric assay. A part of each extract was analyzed by SDS-PAGE and lanes 2 and 4 showed 2 protein bands at molecular weight of 65 and $>75 \mathrm{kDa}$ by silver staining (Figure 6B). Lane 3 showed one more band with molecular weights of $25 \mathrm{kDa}$. The extract of native-PAGE strip 2, which corresponds lane 2, was used for the N-terminal amino acid sequence determination, and the sequence obtained was ATPDEWRSRSIYFMLTDRGA.

A homology search for the partial N-terminal amino acid sequence was performed by fasta program, and the results are shown in Table 2. Enzymes having highly homologous amino acid sequences included $\alpha$-amylase (EC 3.2.1.1) from Thermomyces lanuginosus, Aspergillus niger, and Aspergillus oryzae with homologies of $80.0,80.0$, and $75.0 \%$, respectively. Maltohexaose-producing amylase glucan 1,4- $\alpha$-maltohexaosidase and pullulanase (EC 3.2.1.41) showed 50 to $58 \%$ homology. Therefore, it is suggested that the dextran-degrading enzyme isolated from blue cheese belongs to the $\alpha$-amylase family.

\section{DISCUSSION}

From water-soluble fraction extracted from blue cheese, dextran-degrading enzyme activity was found. It is clear that this activity is due to the enzyme produced by $P$. roquefort because we have observed the enzyme activity in pure culture of this microorganism isolated from blue cheese used in this experiment (data not shown). Certain species of mold such as Penicillium lilacinum, Penicillium funiculosum, Penicillium veruculosum, Spicaria violacea (Tsuchiya et al., 1952), and
Fusarium moniliforme (Simizu et al., 1998), and the yeast Lipomyces starkeyi (Koenig and Day, 1989) are reported to produce extracellular dextran-degrading enzymes. Milk contains lactose, a disaccharide, however, it would be unusual for a polysaccharide such as dextran to be present in milk or cheese. Cellulase activity has been reported in Penicillium camemberti (Jun et al., 1992), but the presence of cellulose in Camembert cheese is unlikely as well. Dextran is synthesized from sucrose by dextransucrase, which is secreted by microorganisms such as Leuconostoc dextranicum and Leuconostoc mesenteroides (Ul-Qader et al., 2001). In blue cheese, which is fermented with mold, one of these microorganisms may be used as a starter culture in the early stage of the production process. Other microorganisms, such as yeast, generally grow on the surface of mold-fermented cheese. It is reasonable that the yeast synthesizes dextran, which may then induce secretion of dextran-degrading enzyme from $P$. roquefort or other microorganisms growing in the cheese. Microorganisms grown on the surface of the cheese are unlikely to contribute to the secretion of this enzyme because enzyme activity was obtained from cheese that had its surface removed.

Penicillium roquefort is one of the major microorganisms that have been used for ripening of cheese for a long time and thus its safety for human health is undeniable. Therefore, the enzyme reported in this article is expected to utilize safely as the products orally ingestible such as food ingredients and oral hygiene products. There is another possibility, which is to use the isomaltooligosaccharides produced by this enzyme as prebiotics, a growth factor for bifidobacteria in intestinal tracts. The utilization of such an enzyme produced 
by microorganisms from fermented milk products is considered to be very advantageous. We are currently working to determine substrate specificity and the full sequence of the enzyme and to develop mass production of the enzyme.

\section{ACKNOWLEDGMENTS}

We are grateful to A. Kimura and A. Hattori for their useful advice and to Yuukichi Abe (Center for Instrumental Analysis, Hokkaido University) for the amino acid sequence determination.

\section{REFERENCES}

Bracq, E., A. Levieux, and D. Levieux. 1997. Purification and immunochemical quantitation of Penicillium roqueforti acid aspartyl proteinase. J. Dairy Res. 64:105-113.

Davis, B. J. 1964. Disc electrophoresis-II. Method and application to human serum proteins. Ann. N.Y. Acad. Sci. 121:404-427.

Jang, K. Y., and Y. D. Hang. 1996. Transfructosylating enzyme activity of Penicillium roquefortii. Lett. Appl. Microbiol. 22:397-399.

Jun, C. W., M. Z. Min, and K. M. Sel. 1992. Purification of the cellulase complex produced by Penicillium camemberti and its partial characterization. Folia Microbiol. 37:199-204.
Koenig, D., and D. Day. 1989. The purification and characterization of a dextranase from Lipomyces starkeyi. Eur. J. Biochem. 183:161-167.

Laemmli, U. 1970. Cleavage of structural proteins during the assembly of the head of bacteriophage T4. Nature 227:680-686.

Larsen, M. D., K. R. Kristiansen, and T. K. Hansen. 1998. Characterization of the proteolytic activity of starter cultures of Penicillium roqueforti for production of blue veined cheeses. Int. J. Food Microbiol. 43:215-221.

Nelson, N. 1944. A photometric adaptation of the Somogyi method for the determination of glucose. J. Biol. Chem. 153:375-380.

Rosenthal, I., S. Bernstein, and B. Rosen. 1996. Alkaline phosphatase activity in Penicillium roqueforti and in blue-veined cheeses. J. Dairy Sci. 79:16-19.

Shimazaki, K., S. K. Maki, Y. Wang, M. Sato, T. Tanaka, and H. Kumura. 2003. Preliminary study and characterization of dextran degradation by the water-soluble fraction extracted from blue cheese. Milchwissenschaft 58:379-382.

Simizu, E., T. Unno, M. Ohba, and G. Okada. 1998. Purification and characterization of an isomaltotriose-producing Endodextranase from a Fusarium sp. Biosci. Biotech. Biochem. 62:117-122.

Somogyi, M. 1952. Notes on sugar determination. J. Biol. Chem. 195:19-23.

Tsuchiya, H. M., A. Jeanes, H. M. Bricker, and C. A. Wilham. 1952. Dextran-degrading enzymes from molds. J. Bacteriol. 64:513519 .

Ul-Qader, S. A., L. Iqbal, H. A. Rizvi, and R. Zuberi. 2001. Production of dextran from sucrose by a newly isolated strain of Leuconostoc mesenteroides (PCSIR-3) with reference to L. mesenteroides NRRL B-512F. Biotechnol. Appl. Biochem. 34:93-97. 